NBER WORKING PAPER SERIES

\title{
THE EFFECTIVENESS OF CIGARETTE REGULATIONS IN REDUCING CASES OF SUDDEN INFANT DEATH SYNDROME
}

\author{
Sara Markowitz \\ Working Paper 12527 \\ http://www.nber.org/papers/w12527
NATIONAL BUREAU OF ECONOMIC RESEARCH
1050 Massachusetts Avenue
Cambridge, MA 02138
September 2006

I would like to thank Andy Racine, Ted Joyce, Pinka Chatterji and Michael Grossman for extremely helpful comments and suggestions. I would also like to thank Frank Chaloupka for providing me with some of the data. The views expressed herein are those of the author(s) and do not necessarily reflect the views of the National Bureau of Economic Research.

(C) 2006 by Sara Markowitz. All rights reserved. Short sections of text, not to exceed two paragraphs, may be quoted without explicit permission provided that full credit, including $\odot$ notice, is given to the source. 
The Effectiveness of Cigarette Regulations in Reducing Cases of Sudden Infant Death Syndrome Sara Markowitz

NBER Working Paper No. 12527

September 2006

JEL No. I0

\begin{abstract}
$\underline{\text { ABSTRACT }}$
Sudden Infant Death Syndrome is a leading cause of mortality among infants and is responsible for thousands of infant deaths every year. Prenatal smoking and postnatal environmental smoke have been identified as strong risk factors for SIDS. Given the link between smoking and SIDS, this paper examines the direct effects of cigarette prices, taxes and clean indoor air laws in explaining changes in the incidence of SIDS over time in the United States. State-level counts of SIDS cases are generated from death certificates for 1973 to 2003. After controlling for some observed and unobserved confounding factors, the results show that higher cigarette prices and taxes are associated with reductions in SIDS cases. Stronger restrictions on smoking in restaurants and child care centers are also effective in reducing SIDS deaths.
\end{abstract}

Sara Markowitz

Rutgers University

Department of Economics

360 Dr. Martin Luther King Jr. Blvd.

Newark, NJ 07102

and NBER

smarkow@rutgers.edu 


\section{INTRODUCTION}

Sudden Infant Death Syndrome (SIDS) is the unexplained, sudden death of an infant

under 1 year of age. SIDS is the leading cause of mortality among infants ages 1-12 months, and is responsible for thousands of infant deaths every year (CDC 2006a). Although much research has been conducted on the correlates of SIDS and related risk factors, the underlying biologic mechanisms causes of SIDS are currently unknown (USDHHS 2006). SIDS cases are usually identified through an autopsy that rules out other identifiable causes of death. The standard definition of the syndrome is "the sudden death of an infant under 1 year of age, which remains unexplained after a thorough case investigation, including performance of a complete autopsy, examination of the death scene, and a review of the clinical history." (American Academy of Pediatrics [AAP] Task Force on SIDS 2005, p. 1245)

Rates of SIDS in the United States have been steadily declining since 1980 (Figure 1). Since then, the number of SIDS cases has fallen from 1.53 per 1000 live births in 1980 to 0.53 per 1000 live births in 2003. The difficulty in identifying the causes of SIDS makes it difficult to attribute reasons for the decline. The "Back to Sleep" campaign, which recommends that infants should be put to sleep in a supine position, has been widely cited for achieving significant reductions in SIDS in the U.S. (Willinger et al. 1998; Pickett et al. 2005; Anderson et al. 2005). However, given that this campaign began in the mid-1990s, there is still much unknown about the trends, causes, and prevention of this syndrome.

Much of the current research on SIDS focuses on identifying the risk factors that are consistently observed to be associated with elevated risks of SIDS. The Centers for Disease Control (CDC) summarizes seven primary risk factors: 1) tummy or side sleeping; 2) soft sleep surfaces; 3) loose bedding; 4) overheating; 5) smoking; 6) bed sharing; and 7) preterm and low 
birth weight (CDC 2006b). The AAP adds that the use of pacifiers may reduce the risk and young maternal age increases it (AAP Task Force on SIDS 2005). For many of these risk factors, public education campaigns may be the only way to encourage the behaviors that will reduce SIDS. For smoking, however, policy makers have a variety of tools besides public education that can be used. Cigarette taxes and laws regulating indoor smoking are known to be strong predictors of smoking behaviors among all adults and pregnant women (Evans and Ringel 1999; Chaloupka and Warner 2000; Tauras 2006). If smoking is truly a causal determinant of SIDS then policies that reduce smoking should have the added benefit of reducing SIDS cases. The purpose of this paper, therefore, is to examine the direct effects of changes in cigarette prices, taxes and clean indoor air laws in explaining changes in the incidence of SIDS over time in the United States.

\section{SMOKING AND SIDS}

A number of studies from the U.S. and other countries around the world have established both prenatal and postnatal smoking as major preventable risk factors for SIDS. In a comprehensive review of this literature, Anderson and Cook (1997) find that maternal smoking doubles the risk of SIDS. They conclude "the relationship is almost certainly causal." (p. 1003) The U.S. Surgeon General's 2006 report on the Health Consequences of Involuntary Exposure to Tobacco Smoke concurs: "The evidence is sufficient to infer a causal relationship between exposure to secondhand smoke and sudden infant death syndrome.” (p. 194).

The mechanism through which smoking influences SIDS is not clear, although it is believed that the immediate cause of death is through the cardiorespiratory system (Anderson and Cook 1997). During pregnancy, smoking may directly alter fetal oxygenation and 
development (Schoendorf and Kiely 1992), or it may affect birth weight, which can have a separate effect on SIDS (CDC 1991). After birth, smoking may lead to an irritation of the airway or respiratory infections, and nicotine may affect ventilatory response functions (Anderson and Cook 1997).

The literature on prenatal smoking and SIDS shows that the risk of dying from SIDS is much higher for infants of mothers who smoked during pregnancy than for those with mothers who did not smoke (Mitchell et al. 1993; Blair et al.1996; Getahun et al. 2004; Anderson et al. 2005). Anderson et al. (2005) attribute a range of 48 percent to 80 percent of the observed SIDS deaths to prenatal maternal smoking, even after controlling for other factors such as birth weight, gestational age, and certain maternal characteristics.

Postnatal smoking by either the mother or other household members also has been shown to be a risk factor for SIDS. For example, case-control studies on maternal smoking postpartum by Schoendorf and Kiely (1992), Mitchell et al. (1993), Klonoff-Cohen et al. (1995), Blair et al. (1996) and others all find a positive relationship between smoking and SIDS, even after controlling for other risk factors such as maternal characteristics, prenatal smoking, and, in some studies, sleep position. The risk of death is also found to rise with increasing levels of smoking (Mitchell et al. 1993; Blair et al.1996). Anderson and Cook (1997) conducted a meta-analysis of postnatal maternal smoking and found that smoking after pregnancy increases the risk of SIDS by 94 percent. Klonoff-Cohen et al. (1995) specifically examine maternal smoking in the same room as the infant show even larger increases in the risk of SIDS over mothers who do not smoke.

Smoking by fathers and other household members is also believed to be associated with an increased risk of SIDS, although the evidence is not consistent across studies (USDHHS 
2006). Controlling for maternal prenatal smoking, Klonoff-Cohen et al. (1995) and Blair et al. (1996) find that children in households with a non-smoking mother but a smoking father have a higher risk of SIDS than children in households with non-smoking parents. Mitchell et al. (1993) also show an increased risk for children in households where household members other than the mother or father smoke, but this result does not hold in models that also include smoking by the parents. However, studies by Brook et al. (1997), Mitchell et al. (1997) and Alm et al. (1998) show statistically insignificant effects for father's smoking.

The above mentioned studies are all case-controlled studies that match families of infants who died to a sample of control families with similar characteristics. Many studies are population based, but often have small sample sizes and focus on restricted geographic areas. The results of the multivariate studies may be biased if the smoking behaviors examined are correlated with other unmeasured risky behaviors that remain in the error term. For example, if people who smoke are less likely to follow the advice of doctors, then it is plausible that they might also ignore the advice to put babies in the supine position for sleeping. The endogeneity problem is particularly prevalent in studies of SIDS in the U.S. that use national level data, such as death certificates or the National Maternal and Infant Health Survey, and do not contain information on sleep position or other sleep-related behaviors (Schoendorf and Kiely 1992; Getahun et al. 2004).

None of the above mention studies analyzes a long time series of SIDS deaths in the United States in an attempt to explain trends over time in the syndrome and the factors associated with changes in the trends. The paper attempts to fill this void in the literature, and does so while avoiding the problems of the endogeneity of smoking behaviors. To my knowledge, this is the first paper that associates long-term trends in smoking and the exogenous determinants of 
smoking to population based SIDS rates in the United States.

\section{CIGARETTE PRICES AND SMOKING}

Research in economics has well established the negative relationship between the price of cigarettes and the quantity demanded. Price elasticity estimates of cigarette sales data range from -0.14 to -1.23 , with a large number of the estimates falling in a narrower range of -0.20 to -0.50 (USDHHS 1994). Estimates from individual level data yield similar estimates, with a consensus price elasticity of demand for adult smoking of -0.4 (Chaloupka and Warner 2000).

In addition to estimating own-price effects, several econometric studies have examined the effects of smoke-free air laws on adult smoking behavior. A majority of these studies find an inverse relationship between the implementation of these laws and smoking (Wasserman et al. 1991; Chaloupka 1992; Evans et al. 1999; Ohsfeldt et al. 1999; Czart, et al. 2001; Gallet 2004). Tauras (2006) finds that more restrictive smoke free air laws decreases average quantities for adult smokers, but have no effects on the prevalence of smoking.

The smoking behaviors of pregnant women are also susceptible to changes in cigarette prices. Using national natality files, Evans and Ringel (1999) and Ringel and Evans (2001) examine the demand for cigarettes among pregnant women and find that higher cigarette taxes are associated with a reduced probability of smoking during pregnancy. They estimate participation price elasticities of -0.5 and -0.7 , respectively. Lien and Evans (2005) confirm these participation results using recent natality data from four states that experienced large cigarette tax changes. Gruber and Köszegi (2001) also use natality data and find negative price effects on the average quantity of cigarettes smoked daily by pregnant women.

Bradford (2003) uses data from the National Maternal and Infant Survey and follow-up to 
examine the relationships between cigarette prices and smoking behaviors for pregnant and nonpregnant women. He finds that while higher prices are negatively associated with the probability of smoking and the quantity of cigarettes smoked, there is no different in the magnitudes of the effects for pregnant and non-pregnant women. Colman et al. (2003) show that higher cigarette taxes are negatively related to the probabilities of smoking before, during and after pregnancy. This study also examines quit and relapse behavior of pregnant women and finds that higher taxes are associated with increased probabilities of quitting prior to pregnancy and quitting before delivery. Higher taxes also decrease the probability that a woman will resume smoking after delivery.

\section{METHODS AND DATA}

The empirical specification is based on the notion that smoking behaviors may lead to SIDS. Therefore, the exogenous determinants of cigarette consumption, for example cigarette prices and regulations, are hypothesized to reduce SIDS rates through decreased consumption. The model is specified as follows:

1) $\quad S_{j t}=f\left(P_{j t}, X_{j t}, r_{j}, q_{j}, a_{t}\right)$.

Equation (1) shows that the number of SIDS cases (S) in a state (j) for a given year and quarter (t) is a function of the full price of cigarettes $\left(\mathrm{P}_{\mathrm{jt}}\right)$, which includes monetary prices and laws regulating smoking, other determinants of SIDS $\left(\mathrm{X}_{\mathrm{jt}}\right)$, year effects $\left(\mathrm{r}_{\mathrm{t}}\right)$, seasonal effects $\left(\mathrm{q}_{\mathrm{t}}\right)$, and state effects $\left(a_{j}\right)$. The principal hypothesis tested is whether or not changes in the full price of cigarettes can explain the changes in SIDS cases over time.

Equation 1 represents a reduced form equation which models SIDS as a direct function of the full price of cigarettes rather than as a function of consumption of cigarettes. The reduced 
form model has two advantages. The first is that the results will suggest viable policy tools, such as increases in cigarette taxes, that may be effective in reducing SIDS. The second is that the results can provide further evidence for the causal relationship between smoking and SIDS. The exogenous determinants of consumption, such as prices, are not expected to affect SIDS except through consumption; thus any result showing that higher prices reduce SIDS is consistent with a causal explanation. The reduced form is a useful strategy for detecting causality when estimates of the structural relationship are biased due to correlation of smoking behaviors and unobserved factors in the error term.

The variables used in Equation 1 are described in detail below. The unit of observation is at the state level, and data for each state is observed quarterly for the years 1973-2003. Quarterly data are used so that the variables representing the full price of smoking (prices, taxes and smoke free air laws) are matched fairly closely to the actual date of death. However, as discussed above, the harm from smoking may occur both from prenatal maternal smoking and from postnatal environmental smoke. These two sources of smoke imply that the cigarette prices, taxes and regulations that existed in both time periods are relevant for this study. Therefore, a second models is considered that includes a one-year lag of the cigarette policy variables. A lag of one year is chosen since the majority of SIDS cases occur in the 2nd and 3rd month of life (AAP Task Force on SIDS 2005). The lagged variables will therefore represent the policies that existed at or near the beginning of the pregnancy for many of the cases of SIDS. This timing is appropriate as most women make their smoking decisions at the beginning of their pregnancy (Evans and Ringel 1999). Lagged and current values of prices and laws are not included in the same models because of the high degree of collinearity across time.

Given that SIDS cases are counts, I use the Fixed Effects Poisson (FEP) estimator to 
estimate the models (Wooldridge 2002; Cameron and Trivedi 1998). This estimator is a quasimaximum likelihood estimator that includes parameters or "fixed effects" to account for unobserved heterogeneity across the units of observation (states). Estimates are consistent regardless of whether the counts actually have a Poisson distribution (Wooldridge 2002). To permit overdispersion, a common feature of count data that is not accommodated by the Poisson maximum likelihood estimator, standard errors are adjusted for heteroskedasticity of unknown form that includes a within-state cluster correlation (Cameron and Trivedi 2005; Bertrand et al. 2004). Each model includes the log of the number of live births in the state for each year as a right hand side variable to normalize for exposure. The coefficient on log births is constrained to equal one. ${ }^{1}$

\section{SIDS Data}

Data on SIDS cases come from the 1973-2003 Multiple Cause of Death files provided by the National Center for Health Statistics (NCHS). SIDS cases first appear in 1973 because there was no specific ICD code for SIDS prior to then (Malloy and MacDorman 2005). Cases of SIDS are identified using ICD codes. In the early years of the data, ICD-8 code 795.0 identifies SIDS cases. From 1979 to 1998, ICD-9 code 798.0 identifies the cases. Data from 1999 on uses the ICD-10 code of "R95" to identify SIDS cases.

Differences in reporting practices across time and states may influence the quarterly SIDS counts. For example, in 1996, the CDC issued a new reporting form for SIDS along with new guidelines regarding the death scene investigation (CDC 1996). This change was implemented because prior practices for case investigation varied greatly among reporting

\footnotetext{
${ }^{1}$ Models were tested using a log-linear model to estimate SIDS rates instead of counts. Results are very similar to those presented here.
} 
jurisdictions. Recent changes in the ICD codes and coding practices may also be responsible for altering the numbers of reported cases. In 1999, a variable signifying "pending investigation" was added to the mortality files. This change allows certifiers to list a tentative cause of death along with the pending investigation designation. Updates to these cases in the natality files are not always received and many cases remain without a cause of death listed (Malloy and MacDorman 2005; Shapiro-Mendoza et al. 2006). The was also a change in the classification rules for SIDS that occurred when switching from the ICD-9 to ICD-10 that may have resulted in a shift in case classifications away from SIDS, towards other unknown/unspecified causes and accidental suffocation or strangulation in bed (Shapiro-Mendoza et al. 2006).

While the reporting issues may affect the observed trends in SIDS, these factors should not influence the conclusions regarding smoking policies in the multivariate analysis. First, changes in the reporting that is uniform to all states at one time can be accounted for by dichotomous indicators for years in the models. Second, so long as the measurement error in the dependent variable is uncorrelated with the explanatory variables of interest, this will raise the standard errors on the coefficients but still produce consistent estimates. The estimated coefficients could be affected if the changes in the reporting practices were systematically related to changes in cigarette prices and policies, however, this possibility seems highly unlikely.

\section{Cigarette Variables}

Cigarette prices and taxes are used as alternative measures of the monetary price of cigarettes. Cigarette price and tax data come from the annual Tax Burden on Tobacco (Orzechowski and Walker 2005). The prices are weighted averages for a pack of 20 cigarettes and are inclusive of state excise taxes. Because the price published is as of November 1 of each 
year, the prices were adjusted to create a state-level average quarterly price. Quarterly taxes are determined using the effective date of legislated tax changes. Cigarette prices and taxes are deflated by the national Consumer Price Index published by the Bureau of Labor Statistics $(1982-1984=100)$.

Three variables representing the degree of smoking restrictions in certain places are included as additional measure of the full price of cigarettes. These smoke free air (SFA) laws are the laws regarding private workplaces, restaurants, and child care centers. These variables were obtained from Gary Giovino at the Roswell Park Cancer Institute who created these variables for project ImpacTeen. The laws are appended to the SIDS data by state, year and quarter, based on the effective dates of the laws. Even though states have SFA laws regarding many different establishments, these three are the focus of this paper because private workplace and restaurant restrictions are very common and research has show there to be an influence of these individual laws on smoking behaviors (Evans et al. 1999; Tauras 2004). Restrictions in child care facilities are included because of the relevance to SIDS.

The variables for private workplaces and restaurants take on four possible values. A zero represents no provisions. A one represents laws that restrict smoking to designated areas or areas with separate ventilation with exemptions for the size of the establishment. A two represents a restriction to areas with separate ventilation or imposes a ban, with exemptions. Finally, a three represents a ban that is present at all times. The values for the child care index range from zero to five. A zero represents no provisions. A one represents laws that restrict smoking to designated areas. A two restricts smoking to areas with separate ventilation or imposes a ban when children are present, with exemptions. A three represents a ban when children are present for commercial day care sites, while a four adds home day care to the ban. A five represents a 
ban at all times for all types of day care arrangements.

Because of the high degree of collinearity between the regulations, each SFA index is included separately in the regressions. The collinearity arises because many states pass SFA laws applicable to different facilities at the same time. The simple correlations between restrictions in private workplaces and restaurants is 0.66 , between private workplaces and child care centers is 0.40 , and between restaurants and child care centers is 0.46 . An alternative model is also presented which combines the above indexes. Termed "smoking ban count", this measure ranges from zero to three and counts the number of bans present in the state. That is, this variable counts the number of times a values of three or greater appears for the private workplace, restaurant, and child care indexes within given state, year and quarter. For example, if none of the locations have a ban in effect then the smoking ban measure takes on a value of zero. If all three locations have a ban, then the measure takes on a value of three.

\section{Temporal and State Variables}

As mentioned above, the "Back to Sleep" campaign has been widely cited as the primary cause for the recent reductions in SIDS cases. In 1992, the American Academy of Pediatrics recommended a side or back sleeping position as a way to reduce SIDS. The national "Back to Sleep" campaign began in 1994 and continues today. In 1996, the AAP advised that the back is the preferred sleep position, as new evidence revealed an increased risk of SIDS for side-sleepers relative to back-sleepers (AAP 2005). It is difficult to know the rate at which the dissemination of information regarding sleep position reached individuals in different states. Therefore, annual time dummies will be used to represent the effects of the campaign. Quarterly time indicators are also included to represent any seasonal changes in SIDS rates. Models were also tested that 
include indicators for each unique year and quarter, and the results do not change. These results are available upon request. The model with separate year and quarter indicators is preferred since the effects of the post-1992 AAP recommendations can be clearly seen with annual time dummies. Also, within each year there is a strong seasonal trend to SIDS with more deaths occurring in the first and forth quarters of the year.

Each model includes some other state-level time varying variables to account for additional factors which may be associated with the number of SIDS cases over time. Maternal characteristics such as low income, low education, and young maternal age are all strongly correlated with an increased the risk of SIDS (Anderson and Cook 1997; Spencer and Logan 2004; Hunt and Hauck 2006). To represent SES status, I include the annual state unemployment rate, the annual real per capita income, and the quarterly average level of education of new mothers in all models. Education is represented as the percentage of mothers giving birth in each state and quarter who have less than a high school education (the omitted reference category), a high school education, some college, or a college degree or higher. ${ }^{2}$ The quarterly average age of first-time mothers is also included. It should be noted that the low SES is not believed to be a causal factor of SIDS, but rather a distal factor that acts through some of the other known risk factors such as low birth weight, smoking, or prone sleeping. Unemployment rates and per capita income come from Department of Labor, Bureau of Labor Statistics and the Department of Commerce, Bureau of Economic Analysis, respectively. The average age of the mother at first live birth and the average education of new mothers are generated from the National Center for Health Statistics Natality files, 1973-2003.

Infant characteristics such as male gender, non-white race, and low birth weight are also

\footnotetext{
${ }^{2}$ Ten states have missing values for education in various years of the data prior to 1992 . These observations represents 5 percent of the sample. To preserve the observations, the sample means replace the missing values. Models were also tested that exclude the education variables and results for the cigarette policies remain unchanged.
} 
associated with higher risk of SIDS (Anderson and Cook 1997; Pickett et al. 2005; Getahun et al. 2004). State-level rates of new births representing these characteristics will be included in the models. ${ }^{3}$ The percentages of births that are male, low birth weight (less than 2500 grams but greater than 1500 grams), and very low birth weight (less than 1500 grams) are generated from the NCHS Natality files for each state and quarter. Note that the low birth weight variables may be problematic in the models since birth weight is also an outcome of prenatal smoking. This issues is examined in further detail below. The percentages of births born to mothers who are identified as black and American Indian/Alaska Natives are also included in all models. Lastly, all models also include state fixed effects to account for unmeasured, time invariant characteristics unique to each state.

\section{RESULTS}

Figure 1 shows rates of SIDS cases over time plotted along with average cigarette prices in the United States. Even this crude picture clearly shows a strong negative relationship between the two variables. SIDS cases per 1000 live births increase from the initial year of 1973 until 1980 thereafter fall almost continuously until 2003. There are two slight increases in 1983 and 2002. By contrast, real cigarette prices decrease until 1981, after which they rise almost continuously, with a brief decline between 1992 and 1994.

Table 1 shows means for all included variables. Column 1 shows the means for the entire period, while columns 2 and 3 shows the means for the beginning and ending periods, 1973 and

\footnotetext{
${ }^{3}$ Better estimates of the relationships between the maternal and infant characteristics and SIDS can be obtained by using individual-level data such as the linked birth-death records from the National Center for Health Statistics. I chose not to use individual level data because the cigarette variables are reported at the state level, and there is no gain to using individual-level data for the estimation of these coefficients. Also, the linked birth and death data are only available from 1983-1991 and 1995-2001 providing far fewer years of data than the Multiple Cause of Death Files. Some of these years do not include information on the death month which would prevent the merge of cigarette variables by quarter and result in a less precise match of the cigarette policies with the date of death.
} 
2003, respectively. Over this thirty-one year period, there are an average of 21 cases of SIDS every quarter. The real average price of a pack of cigarettes is $\$ 1.15$, while the real average state excise tax on a pack is $\$ 0.20$. Smoke free air laws are somewhat lax over the full period with average values of the indexes for private workplaces, restaurants, and child care centers of 0.26 , 0.38 , and 0.66 respectively. However, the means mask the increase in these indexes from no restrictions in any state in 1973 to a majority of states having some kind of restriction in 2003.

\section{Cigarette Sales and Smoking During Pregnancy}

To demonstrate the correlation between smoking and SIDS, I first estimate the structural model where SIDS is regressed on measures of cigarette smoking and the other state-level variables. Estimates of the structural model are not the main focus of this paper because the estimates are potentially biased, and the reduced form, not the structural model, is directly applicable to policy. The literature linking smoking and SIDS discussed above cites smoking as a causal factor for SIDS, nevertheless, in a structural model, the coefficient on smoking can be biased if smoking behaviors are correlated with other unobserved or unmeasured factors that also influence the occurrence of SIDS.

Two measures of smoking are considered. The first is the per capita number of packs of cigarettes sold annually in each state as of June 30 , and the second is the percentage of women in each quarter who gave birth and reported smoking during pregnancy. These measures are chosen to represent postnatal and prenatal smoking, the two ways smoking can affect child health. In the absence of data on children's direct exposure to environmental smoke, sales data provide a crude representation of the possible presence of secondhand smoke.

The sales data come from the Tax Burden on Tobacco (Orzechowski and Walker 2005). 
Since these data are as of June 30 of each year, a given year's sales data is matched to the SIDS counts for the first and second quarter of the same year and the third and forth quarter of the previous year. These results are in the first column of Table 2. However, since there is no quarterly variation in the sales data, an alternative specification is shown in column 2 of Table 2 in which the quarterly data have been aggregated to annual data. In this model, the dependent variable is the total SIDS counts for the first and second quarter of the current year and the third and forth quarter of the previous year. The other right hand side variables are all averages over the relevant quarters.

Rates of smoking during pregnancy are calculated from the NCHS Natality files for each state and quarter, beginning in 1989, the first year that questions were asked on tobacco used during pregnancy. ${ }^{4}$ Any live birth in a given quarter is at risk for SIDS, so estimates of the structural model using this smoking measure will tell the effects of higher proportions of women giving birth who smoked during pregnancy on the current SIDS counts.

Table 2 shows the results of the structural models. Columns 1 and 2 show that the coefficient on per capita sales is positive and statistically significant. From column 2, the results show that an increase of one pack of cigarettes sold per capita is associated with 0.22 more annual SIDS deaths on average. Note that an increase in sales of one pack represents about one percent of the average total sales. The coefficient in column 3 on the percentage of women giving birth who smoked during pregnancy is also positive statistically significant. The magnitude of this effect is fairly large. Every one percentage point increase in the proportion of mothers who smoked during pregnancy is associated with an average increase of 24 SIDS deaths.

\footnotetext{
${ }^{4}$ Information on tobacco use is not collected on the birth certificates in California, Indiana, New York, and South Dakota in various years. These states are omitted from the sample in the relevant years.
} 


\section{Cigarette Policy Results}

Estimates of the reduced form models are presented in Tables 3, 4 and 5. Table 3 includes the price of cigarettes, while Table 4 includes instead the state excise tax on cigarettes. Table 5 presents results from models that include the lagged values of the cigarette variables. Five models are presented in each table. The first includes the monetary price measure along with the state-level maternal and infant characteristics, the unemployment rate and real income per capita, state fixed effects, year fixed effects, and quarter fixed effects. For brevity, the coefficients on fixed effects are not shown, although the results of the year fixed effects are discussed below. The alternative specifications in each table build on the first model and include separately the three smoke free air laws and the smoking ban count in columns 2-5.

Since the variables of interest are continuous measures, the coefficients from the poisson regression can be directly interpreted as semi-elasticities, that is, the percentage change in SIDS cases from a one unit change in the independent variable. For ease of interpretation, I also present an alternative marginal effect in brackets which show the absolute change in the number of SIDS cases from a one unit change in the independent variable. Elasticity estimates are also presented for cigarette prices and taxes at the bottom of each table.

The first row in Table 3 shows the coefficients, t-statistics and marginal effects for the real price of cigarettes. The results show across all models that higher cigarette prices are associated with a reduction in SIDS deaths. A one dollar increase in the price of cigarettes is associated with an average reduction of 7.4 to 8.1 SIDS deaths. In elasticity terms, a ten percent increase in the real price of cigarettes reduces SIDS deaths by a range of 6.7 to 7.4 percent. The coefficients on the smoke free air laws are also negative and three of the four are statistically significant at conventional levels. The coefficient on restrictions in private workplaces is 
significant at about the 12 percent level in a two-tailed test. Each additional restriction placed on smoking decreases SIDS by 0.92 for the private workplace restrictions, by 1.2 for the restaurant restrictions and by 0.39 for the child care center restrictions. The variable representing the number of bans shows that each additional smoking ban is associated with an average reduction of 1.46 SIDS deaths.

Table 4 shows the results where the tax on cigarettes is included instead of the price of cigarettes. The results are qualitatively very similar to those presented in Table 3 . The coefficients on cigarette taxes are all negative and statistically significant, as are three of the four smoke free air variables. The tax elasticities reveal that every ten percent increase in the real taxes on cigarettes reduces SIDS deaths by a range of 1.56 to 1.79 percent. The magnitudes of the effects of the smoke free air laws and the ban count are very similar to those in Table 3 .

The results in Table 5 show the effect of the one year lags of cigarette prices, taxes and smoke free air laws on the current year SIDS counts. Lagging these variables does little to alter the results. All the coefficient on the lagged variables are negative and statistically significant, with the exception of private workplaces. The purpose of lagging the variables is to try to test the hypothesis that prenatal smoking affects SIDS deaths. The results in Table 5 do provide some evidence that prenatal smoking matters since the previous year's cigarette policies are negatively associated with current year SIDS rates. I caution, however, that these results are merely suggestive since the cigarette variables tend to be correlated over time, particularly the SFA laws, which change infrequently.

To help show that the results of the cigarette policy variables are not spurious, I examine the effects of the cigarette variables on two outcomes that should not be related to smoking: 1) infant deaths resulting from motor vehicle accidents and 2) infant deaths from drowning. These 
two outcomes are chosen because they are potentially influenced by risky parental behaviors, as SIDS might be, yet logically should not be causally related to cigarette smoking. Any result here showing that cigarette policies are related to these outcomes could indicate that omitted variables are problematic for the SIDS models. These fatality counts come from NCHS's Multiple Cause of Death files for the same years as the SIDS data.

The results of these "counterfactual" models are presented in Table 6. The results for motor vehicle fatalities are in the first three columns. Column 1 shows the structural model and includes the annual per capita sales of cigarettes, on which the coefficient is positive and statistically significant. It is difficult to explain why higher cigarette sales would directly lead to more infants dying in automobile accidents, so an omitted third factor is likely confounding this result. The results of the reduced form confirm this and show no statistically significant effects for the cigarette prices, taxes, or the smoking ban count. The results for drowning are shown in the last three columns of Table 6 . Here, none of the cigarette variables are statistically significant, as expected, implying that unobservables are not influencing the cigarette policy results.

\section{Year Indicator Results}

As mentioned above, the "Back to Sleep" campaign has often been credited for dramatically reducing the incidence of SIDS. The coefficients on the year indicators in the models provide some measure of the effectiveness of this campaign. Rather than showing the coefficients and marginal effects for all the time dummies, Figure 2 summarizes these results by plotting the predicted SIDS death counts over time. For each year $(t)$, a predicted SIDS count $\left(\hat{S}_{t}\right)$ is calculated by the following formula: 
2) $\hat{S}_{t}=\exp \left(\bar{x} b_{1}+r b_{2}\right)$,

where $b_{1}$ is a vector of coefficients for all of the independent variables excluding the year dummies, $\bar{x}$ is the sample means of these independent variables, $b_{2}$ is the vector of year coefficients and $r$ takes on a value of 1 for the year in question and zero otherwise. ${ }^{5}$ The coefficients are taken from the model in column 5 of Table 3 that includes the price of cigarettes along with the smoking ban count.

The strict interpretation of Figure 2 is that it show the trends in SIDS that occur after accounting for the observable factors that include cigarette policies, and the maternal, infant, and state characteristics. That is, Figure 2 shows the variation in SIDS that is attributed to unobserved annual trends that are common to all states. More generally, this picture shows the trends that can be attributed to the national back to sleep campaigns, along with trends in reporting practices that are common across the country. For reference, the actual unadjusted average annual SIDS counts are plotted against the annual average predicted counts in Figure 2. Note that the actual average state count is not adjusted for the population of live births, however, actual average state rates show a similar pattern.

The predicted trend that is shown in Figure 2 is different from the actual trend in some important ways. First there is an initial increase in predicted SIDS cases. This could be due to increased awareness and reporting of SIDS cases that followed the introduction of the ICD code for SIDS in 1973. This initial increase is followed by as slight decline from 1979 to 1981, after which SIDS increased again. This decline is not observed in the unadjusted data until 1980. The predicted values hit a peak in 1989, the same year as the unadjusted data, and then decline until 1996, with one slight increase in 1991. After 1996, the predicted SIDS counts increase until

\footnotetext{
${ }^{5}$ The calculation also includes the log of the average number of live births with a coefficient of one.
} 
2000. Again, this increase is not observed in the unadjusted data. The predicted averages decrease, increase and slightly decrease again in 2001, 2002 and 2003, respectively. It is interesting to note that 1996 was the year when the CDC issued a new reporting form for SIDS along with new guidelines regarding the death scene investigation. It is likely that these practices are responsible for the increase in predicted SIDS after 1996.

It is not clear from Figure 2 that the "Back to Sleep" campaign is responsible for the downward trend in SIDS cases that began in 1991 and continued through 1996. Recall that while the AAP made its initial recommendation in 1992, the national campaign began in 1994 . Some other unobserved factors have to be responsible for the early years of the downturn. Note also that in 1996 the AAP made its recommendation regarding the back only, rather than the side, as the preferred sleep position. Any resulting reductions in SIDS likely have been masked by the reporting changes issued by the CDC in the same year. In summary, it is impossible to disentangle the effects of the Back to Sleep campaign from other nationwide factors that affected the SIDS rates. Other time series data with more information about exposure to the information and sleeping practices are necessary to adequately evaluate the campaign.

\section{Maternal and Infant Characteristics}

The results of the other included variables in Tables 3, 4, and 5 are somewhat consistent with the findings of previous research on the predictors of SIDS, with a few notable exceptions. Older maternal age is associated with lower SIDS death counts, as is higher per capita income. For both of these variables, however, statistical significance varies somewhat depending on the model considered, but if significance is achieved, it generally ranges between the 5 and 10 percent levels. The education variables, however, show no differences in having larger 
percentages of the state population with high school or college degrees compared to no high school degree.

Previous research has also found that children of non-whites are more likely to die of SIDS. This result is duplicated here for states with larger percentages of mothers who are American Indian/Alaska Natives, but not for states with larger percentages of mothers who are black. It is interesting to note that of all the racial and ethnic groups in the U.S., American Indians and Alaska Natives adults have the highest rates of tobacco use (USDHHS 1998). Previous research has also found low birth weight and male gender to be risk factors for SIDS. Again, these results are not duplicated here. The coefficients on male gender, low birth weight, and very low birth weight are all statistically no different from zero in all models.

One must be cautious in interpreting the coefficients for birth weight because along with SIDS, low birth weight is a possible outcome of prenatal smoking. In fact, birth weights have been used in previous research as dependent variables in models examining the effects of higher cigarette taxes in increasing birth weights (Lein and Evans 2005; Evans and Ringel 1999). This problem is explored in more depth in Table 7. The first column presented here shows results for the maternal and infant characteristics in a model that excludes the cigarette price and policy measures. This is done specifically to examine the coefficients on low birth weight and very low birth weight. By excluding the cigarette policy variables from the model, the coefficients on low birth weight and very low birth weight are positive and become larger in magnitude. However, the standard errors are also high making these coefficients statistically insignificant. Given the potential relationship between the cigarette policy variables and birth weights, additional models are shown in Table 7 that exclude low birth weight and very low birth weight. The results of the cigarette price, tax and SFA laws are all very similar to those shown in the 
previous tables. For brevity, only results for the current price, tax and the smoking ban count are shown here. Excluding the low birth weight variables also does not affect any of the other coefficients. These results should not be surprising given that the birth weight variables do not contribute much to the models.

\section{CONCLUSIONS}

Despite years of research, the causes of SIDS and related prevention strategies have been elusive to researchers and to the public health community. To date, several risk factors have been identified and a national campaign seeks to inform caretakers about the risky practices that may lead to SIDS. While the primary message of the campaign is to put babies in a supine position for sleep, the campaign also stresses the importance of a safe sleep surface and surroundings, which includes a smoke-free environment. While SIDS rates have declined substantially since the early 1990s, thousands of children still die suddenly each year from this unexplained syndrome.

This paper takes a new approach to studying the prevention of SIDS by combining lessons from epidemiology and economics. Epidemiological studies have shown that prenatal maternal smoking and postnatal environmental smoke are major risk factors for SIDS deaths. Research in economics has shown that smoking is influenced by the determinants of the demand for cigarettes, including the monetary price and restrictions on smoking in public places. By combining these two relationships, I show that more stringent cigarette regulations have a distinct and direct impact in reducing SIDS deaths. The largest reduction comes from changes in the monetary price of cigarettes--each ten percent increase in the real price of cigarettes reduces the average number of SIDS deaths by a range of 6.7 to 7.4 percent. A ten percent increase in 
the real taxes on cigarettes reduces SIDS deaths by a range of 1.56 to 1.79 percent. The difference in the magnitude of the price and tax effects is not surprising since taxes make up only a proportion of cigarette prices.

Restrictions on smoking in public places also may be life-saving to babies. I find that each additional restriction placed on smoking decreases the average quarterly SIDS count by 0.92 for the private workplace restrictions, by 1.2 for the restaurant restrictions and by 0.39 for the child care center restrictions. The effectiveness of higher cigarette prices and taxes and more stringent restrictions on smoking in public places holds whether these factors are evaluated contemporaneously with the SIDS cases, or lagged one year to represent the prices policies that existed during the prenatal period.

The results of this paper also contribute to the evidence for the causal relationship between smoking and SIDS, while avoiding the potential biased caused by omitted unobserved variables. Since the exogenous determinants of cigarette smoking should not directly affect SIDS except through consumption, the findings that higher cigarette prices and stricter clean indoor air policies reduces SIDS is consistent with the theory that smoking causes SIDS. In sum, this research highlights the message that a smoke-free environment is very important for the health and well-being of infants. 


\section{REFERENCES}

Alm B, Milerad J, Wennergren G, Skjaerven R, Oyen N, Norvenius G, Daltveit AK, HelwegLarsen K, Markestad T, Irgens LM. A case-control study of smoking and sudden infant death syndrome in the Scandinavian countries, 1992 to 1995: the Nordic Epidemiological SIDS Study. Archives of Disease in Childhood 1998;78(4):329-34. .

American Academy of Pediatrics (AAP). "The Changing Concept of Sudden Infant Death Syndrome: Diagnostic Coding Shifts, Controversies Regarding the Sleeping Environment, and New Variables to Consider in Reducing Risk." Pediatrics, 2005, 116:1245-1255.

Anderson HR and DG Cook. "Passive Smoking and Sudden Infant Death Syndrome: Review of the Epidemiological Evidence. Thorax 1997; 52, 1003-1009,

Anderson ME, Johnson DC, Batal HA. "Sudden Infant Death Syndrome and prenatal maternal smoking: rising attributed risk in the back to sleep era." BMC Medicine, 2005, 3:4, 1-7.

Bertrand, Marianne; Duflo, Esther and Mullainathan, Sendhil. "How Much Should We Trust Differences-in-Differences Estimates?” Quarterly Journal of Economics, February 2004, 119(1), pp. 249-75.

Blair PS, Fleming PJ, Bensley D, Smith I, Bacon C, Taylor E, Berry J, Golding J, Tripp J. Smoking and the sudden infant death syndrome: results from 1993-5 case-control study for confidential inquiry into stillbirths and deaths in infancy. British Medical Journal 1996;313(7051):195-8.

Bradford WD. "Pregnancy and the Demand for Cigarettes." American Economic Review, 93(5): 1752-1763, 2003

Brooke H, Gibson A, Tappin D, Brown H. Case-control study of sudden infant death syndrome in Scotland, 1992-5. British Medical Journal 1997;314(7093):1516-20.

Cameron, CA and PK Trivedi. Regression Analysis of Count Data. Econometric Society Monograph No.30, Cambridge University Press, 1998.

Cameron, CA and PK Trivedi. Microeconometrics Methods and Applications. New York: Cambridge University Press, 2005.

Centers for Disease Control. Notice to Readers: Release of Sudden, Unexplained Infant Death Investigation Reporting Form. MMWR March 3, 2006; 55(No. 8):212-213.

Centers for Disease Control, (2006b). Sudden Infant Death Syndrome (SIDS): Risk Factors, http://www.cdc.gov/SIDS/riskfactors.htm. Accessed July 21, 2006.

Centers for Disease Control, Guidelines for Death Scene Investigation of Sudden, Unexplained Infant Deaths: Recommendations of the Interagency Panel on Sudden Infant Death Syndrome. MMWR 1996; Vol 45, No RR10;1-22.

Centers for Disease Control. "Current Trends Cigarette Smoking Among Reproductive-Aged Women -- Behavioral Risk Factor Surveillance System, 1989 “ $M M W R$, Vol 40, No MM42;October 25, 1991, $719-723$. 
Chaloupka, F.J. "Clean Indoor Air Laws, Addiction, and Cigarette Smoking.” Applied Economics, 24(2), 1992, 193-205.

Chaloupka, FJ and KE Warner. "The Economics of Smoking," in The Handbook of Health Economics, Anthony J. Cuyler and Joseph P. Newhouse (eds.). North-Holland, Elsevier Science B.V.: New York, 2000; 1539-1627.

Colman, Greg, Michael Grossman and Ted Joyce "The effect of cigarette excise taxes on smoking before, during and after pregnancy." Journal of Health Economics Volume 22, Issue 6 , November 2003, Pages 1053-1072

Czart, C., R.L. Pacula, F.J. Chaloupka, and H. Wechsler. "The Impact of Prices and Control Policies on Cigarette Smoking Among College Students." Contemporary Economic Policy, 19(2), 2001, 135-149.

Evans, W.N., M.C. Farrelly, and E. Montgomery. "Do Workplace Smoking Bans Reduce Smoking." American Economic Review, 89(4), 1999, 728-747.

Evans, William N. and Jeanne Ringel, "Can Higher Cigarette Taxes Improve Birth Outcomes?" Journal of Public Economic, 72, 1999, 135-154.

Gallet, CA. "The Efficacy of State-Level Antismoking Laws: Demand and Supply Considerations." Journal of Economics and Finance, 28:(3), 2004, 404-412.

Getahun D, Amre D, Rhoads GG, Demissie K. "Maternal and obstetric risk factors for sudden infant death syndrome in the United States." Obstetrics and Gynecology. 2004 Apr;103(4):646-52.

Gruber, Jonathan and Botond Koszegi. "Is Addiction "Rational"? Theory And Evidence." The Quarterly Journal of Economics, November 2001, 116 (4), p1261-1303

Hunt, Carl E. and Fern R. Hauck. "Sudden infant death syndrome." CMAJ • June 20, 2006; 174 (13). 1861-1869.

Klonoff-Cohen HS, Edelstein SL, Lefkowitz ES, Srinivasan IP, Kaegi D, Chang JC, Wiley KJ. The effect of passive smoking and tobacco exposure through breast milk on sudden infant death syndrome. Journal of the American Medical Association 1995;273(10):795-8.

Lien, Diana Stech and William N. Evans, "Estimating the Impact of Large Cigarette Tax Hikes: The Case of Maternal Smoking and Low Birth Weight." Journal of Human Resources. 40(2): 2005, 373-392

Malloy, Michael H. and Marian MacDorman Changes in the Classification of Sudden Unexpected Infant Deaths: United States, 1992-2001

Pediatrics 2005; 115: 1247-1253

Mitchell EA, Ford RP, Stewart AW, Taylor BJ, Becroft DM, Thompson JM, Scragg R, Hassall IB, Barry DM, Allen EM. Smoking and the sudden infant death syndrome. Pediatrics 1993;91(5):893-6.

Mitchell EA, Tuohy PG, Brunt JM, Thompson JM, Clements MS, Stewart AW, Ford RP, Taylor BJ. Risk factors for sudden infant death syndrome following the prevention campaign in New Zealand: a prospective study. Pediatrics 1997;100(5):835-40. 
National Center for Health Statistics. Data File Documentations, Natality, 1973-2003 (machine readable data file and documentation, CD-ROM), National Center for Health Statistics, Hyattsville, Maryland.

National Center for Health Statistics. Data File Documentations, Multiple Cause-of-Death, 19732003 (machine readable data file and documentation, CD-ROM), National Center for Health Statistics, Hyattsville, Maryland.

Ohsfeldt, R.L., R.G. Boyle, and E.L. Capilouto. "Tobacco Taxes, Smoking Restrictions, and Tobacco Use." in The Economic Analysis of Substance Use and Abuse: An Integration of Econometric and Behavioral Economic Research, edited by Frank Chaloupka, Michael Grossman, Warren Bickel, and Henry Saffer. Chicago: The University of Chicago Press, 1999, 15-30.

Orzechowski and Walker. Tax Burden on Tobacco: Historical Compilation, 2005.

Pickett KE, Luo Y, Lauderdale DS. "Widening social inequalities in risk for sudden infant death syndrome.” Am J Public Health. 2005 Nov;95(11):1976-81.

Ringel, Jeanne S.and William N. Evans "Cigarette Taxes and Maternal Smoking." American Journal of Public Health, vol 91, no. 11, November 2001, 1851-1856.

Schoendorf, KC and JL Kiely. "Relationhip of Sudden infant death syndrome to Maternal Smoking During and After Pregnancy." Pediatrics, 2006; 90(6), 905-908.

Shapiro-Mendoza, Carrie K. Kay M. Tomashek, Robert N. Anderson and Jennifer Wingo "Recent National Trends in Sudden, Unexpected Infant Deaths: More Evidence Supporting a Change in Classification or Reporting" American Journal of Epidemiology, Volume 163, Number 8, p. $762-769$.

Spencer N, and Logan S. Sudden unexpected death in infancy and socioeconomic status: a systematic review. Journal of Epidemiology and Community Health 2004 May;58(5):366-73.

Tauras, J.A., "Public Policy And Some-Day Smoking Among Adults" Journal of Applied Economics, 7(1), 2004, 137-162.

Tauras, J.A., "Smoke Free Air Laws, Cigarette Prices, and Adult Cigarette Demand," Economic Inquiry, 44(2): 333-342, 2006.

U.S. Dept. of Health and Human Services. The health consequences of involuntary exposure to tobacco smoke : a report of the Surgeon General. Atlanta, Ga. : U.S. Dept. of Health and Human Services, Centers for Disease Control and Prevention, Coordinating Center for Health Promotion, National Center for Chronic Disease Prevention and Health Promotion, Office on Smoking and Health, 2006.

U.S. Department of Health and Human Services. Tobacco Use Among U.S. Racial/Ethnic Minority Groups-African Americans, American Indians and Alaska Natives, Asian Americans and Pacific Islanders, and Hispanics: A Report of the Surgeon General. Atlanta, Georgia: U.S. Department of Health and Human Services, Centers for Disease Control and Prevention, National Center for Chronic Disease Prevention and Health Promotion, Office on Smoking and Health, 1998. 
U.S. Department of Health and Human Services. Preventing Tobacco Use Among Young People: A Report of the Surgeon General. Public Health Service, Center for Disease Control and Prevention, National Center for Chronic Disease Prevention and Health Promotion, Office on Smoking and Health: Atlanta, Georgia, 1994.

Wasserman, J., W.G. Manning, J.P. Newhouse, and J.D. Winkler. "The Effects of Excise Taxes and Regulations on Cigarette Smoking." Journal of Health Economics, 10(1), 1991, 4364.

Willinger, Marian; Howard J. Hoffman; Kuo-Tsung Wu; Jin-Rong Hou; Ronald C. Kessler; Sally L. Ward; Thomas G. Keens; Michael J. Corwin. "Factors Associated With the Transition to Nonprone Sleep Positions of Infants in the United States: The National Infant Sleep Position Study.” JAMA. 1998;280:329-335.

Wooldridge, Jeffrey M., Econometric Analysis of Cross Section and Panel Data, Cambridge, MA: MIT Press, 2002. 


\section{Figure 1: National SIDS rates and Cigarette Prices}

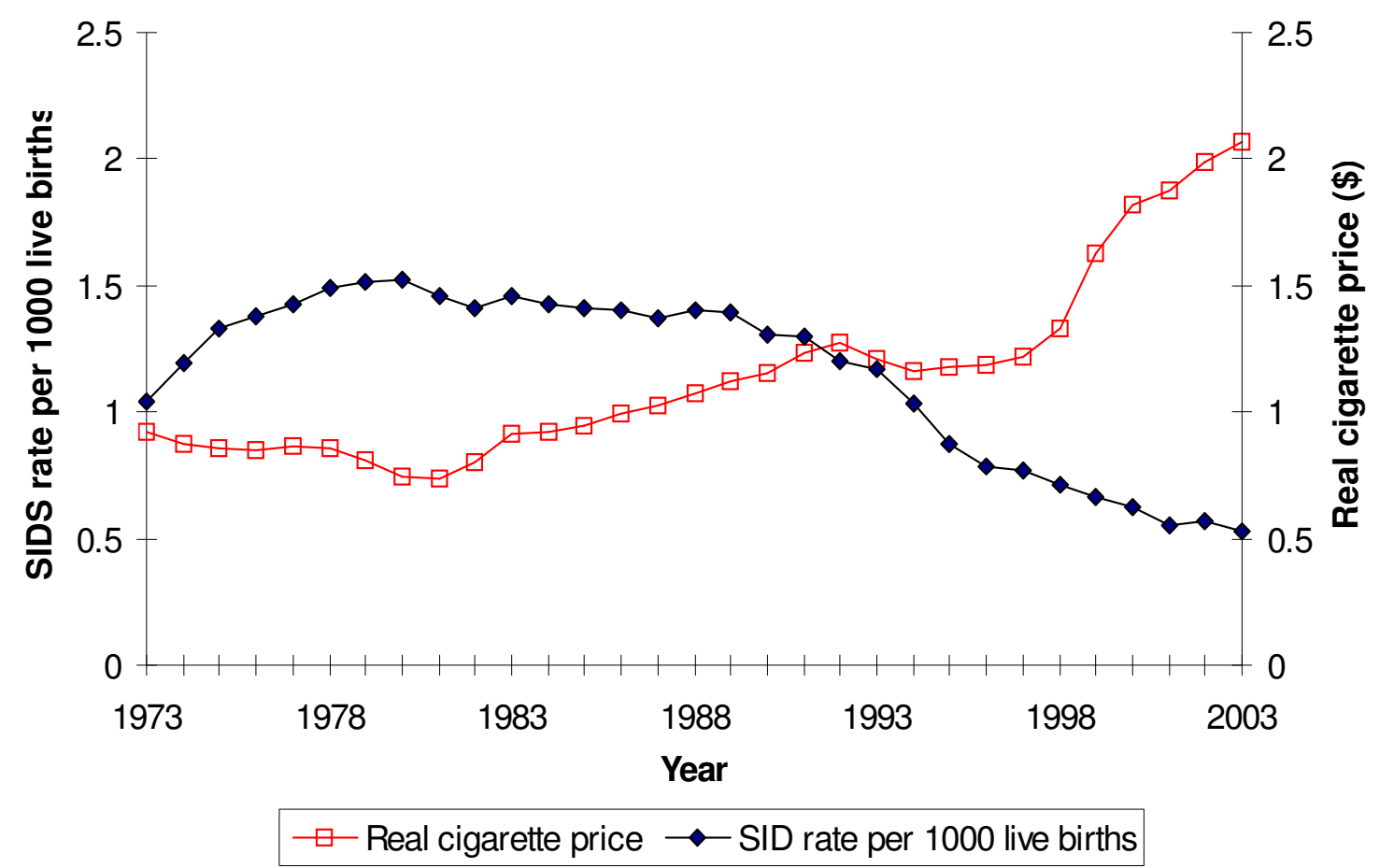

Sources: National Center for Health Statistics, Orzechowski and Walker (2005)

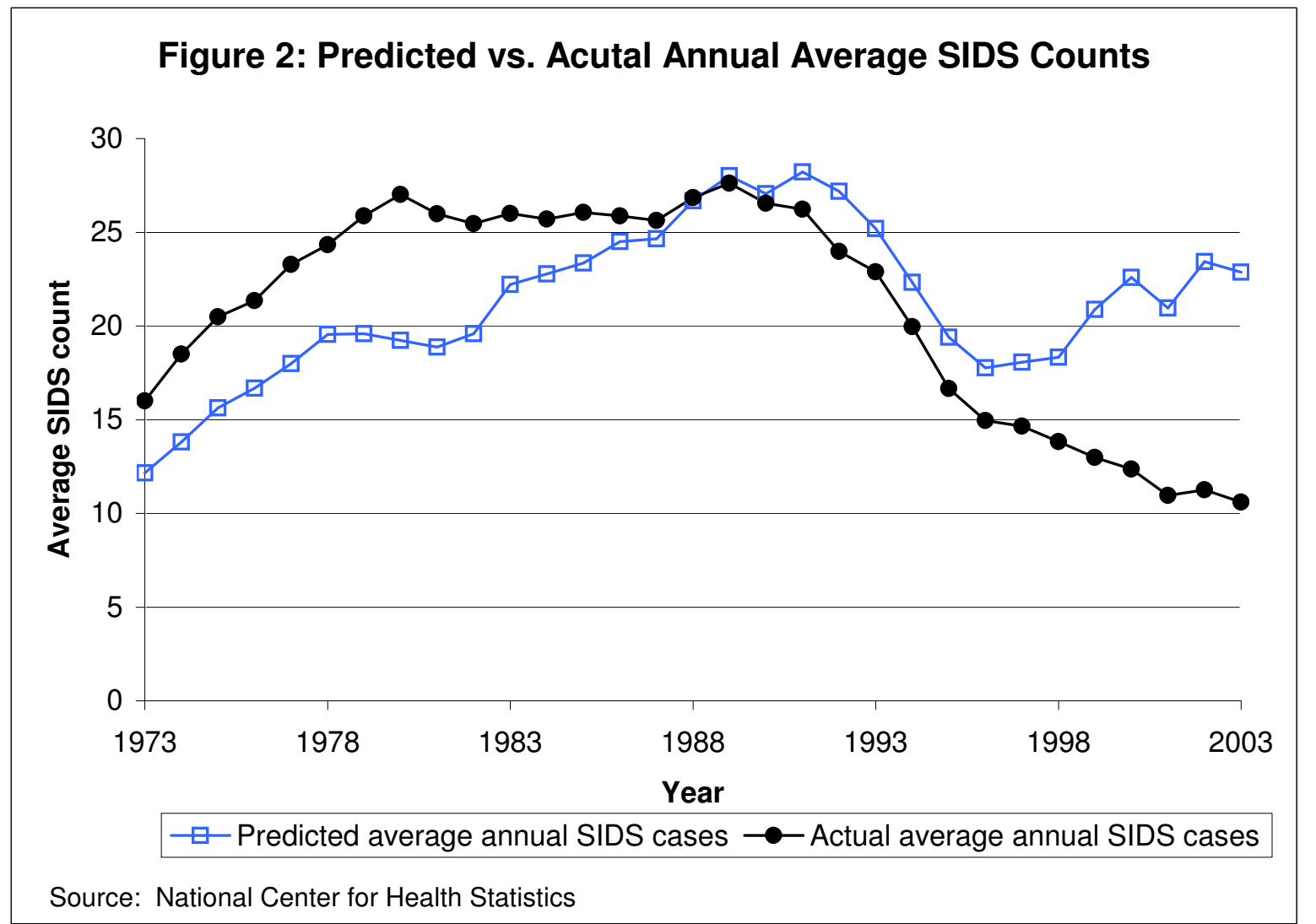


Table 1

Means and Standard Deviations

\begin{tabular}{|c|c|c|c|c|c|c|}
\hline & \multicolumn{2}{|c|}{$\begin{array}{l}\text { All years } \\
(\mathrm{n}=6,324)\end{array}$} & \multicolumn{2}{|c|}{$\begin{array}{l}\text { First Year: } 1973 \\
\qquad(\mathrm{n}=204)\end{array}$} & \multicolumn{2}{|c|}{$\begin{array}{l}\text { Last Year: } 2003 \\
\quad(\mathrm{n}=204)\end{array}$} \\
\hline & Mean & $\begin{array}{l}\text { Standard } \\
\text { Deviation }\end{array}$ & Mean & $\begin{array}{l}\text { Standard } \\
\text { Deviation }\end{array}$ & Mean & $\begin{array}{l}\text { Standard } \\
\text { Deviation }\end{array}$ \\
\hline SIDS count & 20.96 & 24.74 & 16.00 & 16.55 & 10.60 & 10.76 \\
\hline Real cigarette price & 1.15 & 0.39 & 0.92 & 0.11 & 2.06 & 0.32 \\
\hline Real cigarette tax & 0.20 & 0.12 & 0.26 & 0.10 & 0.37 & 0.26 \\
\hline SFA: private workplace & 0.26 & 0.50 & 0.00 & 0.00 & 0.69 & 0.89 \\
\hline SFA: restaurant & 0.38 & 0.60 & 0.00 & 0.00 & 0.84 & 0.89 \\
\hline SFA: child care center & 0.66 & 1.33 & 0.00 & 0.00 & 2.10 & 1.74 \\
\hline Smoking ban count & 0.18 & 0.44 & 0.00 & 0.00 & 0.69 & 0.78 \\
\hline Maternal age at first birth & 23.54 & 1.44 & 21.42 & 0.70 & 25.00 & 1.28 \\
\hline High school degree & 0.39 & 0.06 & 0.44 & 0.05 & 0.30 & 0.07 \\
\hline Some college & 0.21 & 0.05 & 0.17 & 0.05 & 0.22 & 0.06 \\
\hline College or more & 0.19 & 0.07 & 0.12 & 0.04 & 0.26 & 0.09 \\
\hline $\begin{array}{l}\text { Black } \\
\text { American Indian/Alaska }\end{array}$ & 0.14 & 0.15 & 0.13 & 0.15 & 0.13 & 0.14 \\
\hline Native & 0.02 & 0.04 & 0.02 & 0.04 & 0.02 & 0.05 \\
\hline Other race & 0.03 & 0.09 & 0.02 & 0.09 & 0.05 & 0.09 \\
\hline Female baby & 0.49 & 0.01 & 0.49 & 0.01 & 0.49 & 0.01 \\
\hline Low birth weight & 0.06 & 0.01 & 0.06 & 0.01 & 0.07 & 0.01 \\
\hline Very low birth weight & 0.01 & 0.004 & 0.01 & 0.003 & 0.01 & 0.004 \\
\hline State unemployment & 6.05 & 2.07 & 4.83 & 1.45 & 5.65 & 1.04 \\
\hline $\begin{array}{l}\text { State real income per capita } \\
\text { (in } \$ 1,000 \mathrm{~s} \text { ) }\end{array}$ & 13.75 & 2.78 & 11.46 & 1.70 & 16.71 & 2.64 \\
\hline $\begin{array}{l}\text { State per capita cigarette } \\
\text { sales (in packs) } \\
\text { Maternal smoking during }\end{array}$ & 109.86 & 33.98 & 132.32 & 35.15 & 75.29 & 31.02 \\
\hline pregnancy & 0.16 & 0.05 & -- & -- & 0.13 & 0.05 \\
\hline
\end{tabular}

Note: The unit of observation is a state in each year and quarter of the data. 
Table 2: SIDS Counts on Cigarette Sales and Smoking During Pregnancy

\begin{tabular}{|c|c|c|c|}
\hline & (1) & (2) & (3) \\
\hline Per capita cigarette sales & $\begin{array}{l}0.006 \\
(4.61) \\
{[0.070]}\end{array}$ & $\begin{array}{l}0.005 \\
(4.25) \\
{[0.222]} \\
\end{array}$ & \\
\hline Smoking during pregnancy & & & $\begin{array}{c}2.402 \\
(2.61) \\
{[23.848]}\end{array}$ \\
\hline Maternal age at first birth & $\begin{array}{l}-0.103 \\
(-1.66) \\
{[-1.306]}\end{array}$ & $\begin{array}{l}-0.107 \\
(-1.86) \\
{[-5.236]}\end{array}$ & $\begin{array}{l}0.146 \\
(2.21) \\
{[1.449]}\end{array}$ \\
\hline High school degree & $\begin{array}{l}-0.117 \\
(-0.32) \\
{[-1.481]}\end{array}$ & $\begin{array}{c}-0.233 \\
(-0.65) \\
{[-11.376]}\end{array}$ & $\begin{array}{l}-0.659 \\
(-0.94) \\
{[-6.540]}\end{array}$ \\
\hline Some college & $\begin{array}{l}0.239 \\
(0.23) \\
{[3.025]}\end{array}$ & $\begin{array}{l}0.114 \\
(0.11) \\
{[5.538]}\end{array}$ & $\begin{array}{c}2.600 \\
(1.84) \\
{[25.815]}\end{array}$ \\
\hline College or more & $\begin{array}{c}1.044 \\
(1.21) \\
{[13.239]} \\
\end{array}$ & $\begin{array}{c}0.658 \\
(0.66) \\
{[32.058]}\end{array}$ & $\begin{array}{l}-0.194 \\
(-0.19) \\
{[-1.931]}\end{array}$ \\
\hline Black & $\begin{array}{l}-0.623 \\
(-1.27) \\
{[-7.905]}\end{array}$ & $\begin{array}{c}-0.611 \\
(-1.04) \\
{[-29.756]}\end{array}$ & $\begin{array}{l}0.482 \\
(0.73) \\
{[4.783]} \\
\end{array}$ \\
\hline American Indian/Alaska Natives & $\begin{array}{c}5.045 \\
(1.92) \\
{[63.973]} \\
\end{array}$ & $\begin{array}{c}7.008 \\
(2.45) \\
{[341.534]} \\
\end{array}$ & $\begin{array}{c}8.461 \\
(2.46) \\
{[84.017]} \\
\end{array}$ \\
\hline Other race & $\begin{array}{c}-4.438 \\
(-3.63) \\
{[-56.285]} \\
\end{array}$ & $\begin{array}{c}-4.990 \\
(-3.95) \\
{[-243.170]}\end{array}$ & $\begin{array}{c}-4.932 \\
(-1.74) \\
{[-48.968]}\end{array}$ \\
\hline Female baby & $\begin{array}{l}0.142 \\
(0.16) \\
{[1.807]}\end{array}$ & $\begin{array}{c}2.502 \\
(0.93) \\
{[121.942]}\end{array}$ & $\begin{array}{c}-1.091 \\
(-0.80) \\
{[-10.830]}\end{array}$ \\
\hline Low birth weight & $\begin{array}{l}0.582 \\
(0.23) \\
{[7.384]}\end{array}$ & $\begin{array}{c}10.345 \\
(2.03) \\
{[504.132]}\end{array}$ & $\begin{array}{c}-1.945 \\
(-0.70) \\
{[-19.315]}\end{array}$ \\
\hline Very low birth weight & $\begin{array}{c}2.212 \\
(0.47) \\
{[28.056]}\end{array}$ & $\begin{array}{c}12.662 \\
(1.08) \\
{[617.088]}\end{array}$ & $\begin{array}{c}6.397 \\
(1.00) \\
{[63.522]}\end{array}$ \\
\hline State unemployment & $\begin{array}{l}-0.002 \\
(-0.20) \\
{[-0.020]}\end{array}$ & $\begin{array}{l}0.003 \\
(0.33) \\
{[0.144]} \\
\end{array}$ & $\begin{array}{l}-0.019 \\
(-1.50) \\
{[-0.185]}\end{array}$ \\
\hline State real income per capita & $\begin{array}{l}-0.048 \\
(-1.69) \\
{[-0.614]}\end{array}$ & $\begin{array}{l}-0.028 \\
(-0.84) \\
{[-1.358]}\end{array}$ & $\begin{array}{l}-0.016 \\
(-0.58) \\
{[-0.159]}\end{array}$ \\
\hline $\mathrm{N}$ & 6324 & 1632 & 2872 \\
\hline
\end{tabular}

Note: Z-statistics in parentheses, and intercept not shown. Brackets show marginal effects; the change in the average quarterly SIDS count from a one unit change in the independent variable. Coefficients can be interpreted as the percentage change in the average quarterly SIDS count from a one unit change in the independent variable. Column 1 uses quarterly data from 1973-2003. Column 2 uses annual data from 1973-2003. Column 3 uses quarterly data from 1989-2003. All models also include year and state dummy variables. Columns 1 and 3 also include quarterly dummies. 
Table 3: SIDS Counts on Cigarette Prices and Smoke Free Air Laws

\begin{tabular}{|c|c|c|c|c|c|}
\hline & (1) & (2) & (3) & (4) & $(5)$ \\
\hline Real cigarette price & $\begin{array}{l}-0.644 \\
(-3.98) \\
{[-8.133]}\end{array}$ & $\begin{array}{l}-0.626 \\
(-4.36) \\
{[-7.914]}\end{array}$ & $\begin{array}{l}-0.590 \\
(-4.35) \\
{[-7.450]}\end{array}$ & $\begin{array}{l}-0.612 \\
(-4.05) \\
{[-7.731]}\end{array}$ & $\begin{array}{l}-0.583 \\
(-4.17) \\
{[-7.370]}\end{array}$ \\
\hline SFA: private workplace & & $\begin{array}{l}-0.073 \\
(-1.57) \\
{[-0.921]}\end{array}$ & & & \\
\hline SFA: restaurant & & & $\begin{array}{l}-0.099 \\
(-4.62) \\
{[-1.245]}\end{array}$ & & \\
\hline SFA: child care center & & & & $\begin{array}{l}-0.031 \\
(-2.26) \\
{[-0.394]}\end{array}$ & \\
\hline Smoking ban count & & & & & $\begin{array}{l}-0.115 \\
(-2.84) \\
{[-1.455]}\end{array}$ \\
\hline Maternal age at first birth & $\begin{array}{l}-0.124 \\
(-1.79) \\
{[-1.571]}\end{array}$ & $\begin{array}{l}-0.094 \\
(-1.51) \\
{[-1.189]}\end{array}$ & $\begin{array}{l}-0.083 \\
(-1.31) \\
{[-1.043]}\end{array}$ & $\begin{array}{l}-0.115 \\
(-1.80) \\
{[-1.458]}\end{array}$ & $\begin{array}{l}-0.106 \\
(-1.76) \\
{[-1.339]}\end{array}$ \\
\hline High school degree & $\begin{array}{l}-0.472 \\
(-1.18) \\
{[-5.959]}\end{array}$ & $\begin{array}{l}-0.491 \\
(-1.21) \\
{[-6.205]}\end{array}$ & $\begin{array}{l}-0.442 \\
(-1.10) \\
{[-5.584]}\end{array}$ & $\begin{array}{l}-0.481 \\
(-1.26) \\
{[-6.083]}\end{array}$ & $\begin{array}{l}-0.401 \\
(-1.09) \\
{[-5.067]}\end{array}$ \\
\hline Some college & $\begin{array}{l}0.572 \\
(0.60) \\
{[7.219]}\end{array}$ & $\begin{array}{l}0.453 \\
(0.49) \\
{[5.727]}\end{array}$ & $\begin{array}{l}0.294 \\
(0.34) \\
{[3.713]}\end{array}$ & $\begin{array}{l}0.418 \\
(0.46) \\
{[5.281]}\end{array}$ & $\begin{array}{l}0.317 \\
(0.36) \\
{[4.011]}\end{array}$ \\
\hline College $\mathrm{o}$ & $\begin{array}{c}0.796 \\
(0.98) \\
{[10.057]} \\
\end{array}$ & $\begin{array}{c}0.854 \\
(1.11) \\
{[10.790]} \\
\end{array}$ & $\begin{array}{c}0.962 \\
(1.35) \\
{[12.162]} \\
\end{array}$ & $\begin{array}{c}1.057 \\
(1.42) \\
{[13.363]} \\
\end{array}$ & $\begin{array}{c}1.011 \\
(1.42) \\
{[12.777]} \\
\end{array}$ \\
\hline Black & $\begin{array}{l}-0.339 \\
(-0.62) \\
{[-4.285]}\end{array}$ & $\begin{array}{l}-0.329 \\
(-0.59) \\
{[-4.152]}\end{array}$ & $\begin{array}{l}-0.386 \\
(-0.66) \\
{[-4.877]}\end{array}$ & $\begin{array}{l}-0.361 \\
(-0.66) \\
{[-4.560]}\end{array}$ & $\begin{array}{l}-0.375 \\
(-0.66) \\
{[-4.745]}\end{array}$ \\
\hline American Indian/Alaska Natives & $\begin{array}{c}6.003 \\
(2.29) \\
{[75.809]}\end{array}$ & $\begin{array}{c}6.014 \\
(2.22) \\
{[75.983]}\end{array}$ & $\begin{array}{c}5.997 \\
(2.16) \\
{[75.783]}\end{array}$ & $\begin{array}{c}6.312 \\
(2.23) \\
{[79.769]}\end{array}$ & $\begin{array}{c}6.112 \\
(2.09) \\
{[77.256]}\end{array}$ \\
\hline Other race & $\begin{array}{c}-4.368 \\
(-4.54) \\
{[-55.153]} \\
\end{array}$ & $\begin{array}{c}-4.022 \\
(-4.13) \\
{[-50.822]}\end{array}$ & $\begin{array}{c}-3.758 \\
(-4.29) \\
{[-47.489]}\end{array}$ & $\begin{array}{c}-4.113 \\
(-4.46) \\
{[-51.981]}\end{array}$ & $\begin{array}{c}-3.855 \\
(-4.12) \\
{[-48.725]} \\
\end{array}$ \\
\hline Female baby & $\begin{array}{l}0.067 \\
(0.07) \\
{[0.849]}\end{array}$ & $\begin{array}{l}0.052 \\
(0.06) \\
{[0.663]}\end{array}$ & $\begin{array}{l}0.072 \\
(0.08) \\
{[0.904]}\end{array}$ & $\begin{array}{l}0.069 \\
(0.08) \\
{[0.877]}\end{array}$ & $\begin{array}{l}0.050 \\
(0.05) \\
{[0.637]}\end{array}$ \\
\hline Low birth weight & $\begin{array}{c}2.146 \\
(0.86) \\
{[27.094]} \\
\end{array}$ & $\begin{array}{c}1.987 \\
(0.87) \\
{[25.111]} \\
\end{array}$ & $\begin{array}{c}1.490 \\
(0.65) \\
{[18.825]}\end{array}$ & $\begin{array}{c}1.692 \\
(0.69) \\
{[21.387]}\end{array}$ & $\begin{array}{c}1.386 \\
(0.57) \\
{[17.522]} \\
\end{array}$ \\
\hline Very low birth weight & $\begin{array}{l}-0.176 \\
(-0.04) \\
{[-2.224]}\end{array}$ & $\begin{array}{l}-0.408 \\
(-0.09) \\
{[-5.158]}\end{array}$ & $\begin{array}{c}-1.369 \\
(-0.32) \\
{[-17.303]}\end{array}$ & $\begin{array}{l}0.135 \\
(0.03) \\
{[1.708]}\end{array}$ & $\begin{array}{l}-0.086 \\
(-0.02) \\
{[-1.082]}\end{array}$ \\
\hline
\end{tabular}




\begin{tabular}{|l|c|c|c|c|c|}
\hline State unemployment & -0.006 & -0.006 & -0.007 & -0.008 & -0.007 \\
& $(-0.77)$ & $(-0.77)$ & $(-0.97)$ & $(-0.87)$ & $(-0.89)$ \\
& {$[-0.080]$} & {$[-0.073]$} & {$[-0.085]$} & {$[-0.095]$} & {$[-0.093]$} \\
\hline State real income per capita & -0.040 & -0.045 & -0.060 & -0.048 & -0.052 \\
& $(-1.38)$ & $(-1.73)$ & $(-2.41)$ & $(-1.94)$ & $(-2.22)$ \\
& {$[-0.500]$} & {$[-0.567]$} & {$[-0.760]$} & {$[-0.607]$} & {$[-0.658]$} \\
\hline Price elasticity & -0.740 & -0.720 & -0.677 & -0.703 & -0.670 \\
\hline \hline
\end{tabular}

Note: Z-statistics in parentheses, and intercept not shown. Brackets show marginal effects; the change in the average quarterly SIDS count from a one unit change in the independent variable. Coefficients can be interpreted as the percentage change in the average quarterly SIDS count from a one unit change in the independent variable. All models also include year, quarter, and state dummy variables. N=6,324. 
Table 4: SIDS Counts on Cigarette Tax and Smoke Free Air Laws

\begin{tabular}{|c|c|c|c|c|c|}
\hline & (1) & (2) & (3) & (4) & (5) \\
\hline Real cigarette price & $\begin{array}{c}-0.899 \\
(-3.95) \\
{[-11.354]}\end{array}$ & $\begin{array}{c}-0.851 \\
(-4.32) \\
{[-10.754]}\end{array}$ & $\begin{array}{l}-0.785 \\
(-4.18) \\
{[-9.913]}\end{array}$ & $\begin{array}{c}-0.843 \\
(-4.00) \\
{[-10.646]}\end{array}$ & $\begin{array}{l}-0.790 \\
(-4.11) \\
{[-9.981]}\end{array}$ \\
\hline SFA: private workplace & & $\begin{array}{l}-0.059 \\
(-1.34) \\
{[-0.749]}\end{array}$ & & & \\
\hline SFA: restaurant & & & $\begin{array}{l}-0.089 \\
(-4.11) \\
{[-1.118]}\end{array}$ & & \\
\hline SFA: child care center & & & & $\begin{array}{l}-0.028 \\
(-2.16) \\
{[-0.350]}\end{array}$ & \\
\hline Smoking ban count & & & & & $\begin{array}{l}-0.103 \\
(-2.67) \\
{[-1.296]}\end{array}$ \\
\hline Maternal age at first birth & $\begin{array}{l}-0.121 \\
(-1.76) \\
{[-1.521]}\end{array}$ & $\begin{array}{l}-0.097 \\
(-1.55) \\
{[-1.228]}\end{array}$ & $\begin{array}{l}-0.085 \\
(-1.34) \\
{[-1.078]}\end{array}$ & $\begin{array}{l}-0.113 \\
(-1.75) \\
{[-1.432]}\end{array}$ & $\begin{array}{l}-0.106 \\
(-1.72) \\
{[-1.337]}\end{array}$ \\
\hline High school degree & $\begin{array}{l}-0.543 \\
(-1.35) \\
{[-6.857]}\end{array}$ & $\begin{array}{l}-0.541 \\
(-1.33) \\
{[-6.837]}\end{array}$ & $\begin{array}{l}-0.484 \\
(-1.19) \\
{[-6.111]}\end{array}$ & $\begin{array}{l}-0.539 \\
(-1.40) \\
{[-6.814]}\end{array}$ & $\begin{array}{l}-0.455 \\
(-1.23) \\
{[-5.756]}\end{array}$ \\
\hline Some college & $\begin{array}{l}0.533 \\
(0.57) \\
{[6.724]}\end{array}$ & $\begin{array}{l}0.448 \\
(0.49) \\
{[5.657]}\end{array}$ & $\begin{array}{l}0.304 \\
(0.35) \\
{[3.843]}\end{array}$ & $\begin{array}{l}0.404 \\
(0.45) \\
{[5.103]}\end{array}$ & $\begin{array}{l}0.321 \\
(0.36) \\
{[4.060]}\end{array}$ \\
\hline College or more & $\begin{array}{c}0.854 \\
(1.09) \\
{[10.782]} \\
\end{array}$ & $\begin{array}{c}0.901 \\
(1.19) \\
{[11.385]}\end{array}$ & $\begin{array}{c}1.002 \\
(1.42) \\
{[12.659]} \\
\end{array}$ & $\begin{array}{c}1.084 \\
(1.48) \\
{[13.697]}\end{array}$ & $\begin{array}{c}1.043 \\
(1.48) \\
{[13.177]} \\
\end{array}$ \\
\hline Black & $\begin{array}{l}-0.431 \\
(-0.78) \\
{[-5.443]}\end{array}$ & $\begin{array}{l}-0.419 \\
(-0.74) \\
{[-5.290]}\end{array}$ & $\begin{array}{l}-0.463 \\
(-0.79) \\
{[-5.848]}\end{array}$ & $\begin{array}{l}-0.445 \\
(-0.80) \\
{[-5.620]}\end{array}$ & $\begin{array}{l}-0.453 \\
(-0.79) \\
{[-5.731]}\end{array}$ \\
\hline American Indian/Alaska Natives & $\begin{array}{c}5.318 \\
(1.97) \\
{[67.132]}\end{array}$ & $\begin{array}{c}5.387 \\
(1.93) \\
{[68.039]}\end{array}$ & $\begin{array}{c}5.443 \\
(1.90) \\
{[68.771]}\end{array}$ & $\begin{array}{c}5.653 \\
(1.95) \\
{[71.426]}\end{array}$ & $\begin{array}{c}5.531 \\
(1.84) \\
{[69.901]}\end{array}$ \\
\hline Other race & $\begin{array}{c}-4.395 \\
(-4.48) \\
{[-55.476]}\end{array}$ & $\begin{array}{c}-4.165 \\
(-4.18) \\
{[-52.605]}\end{array}$ & $\begin{array}{c}-3.931 \\
(-4.34) \\
{[-49.673]}\end{array}$ & $\begin{array}{c}-4.202 \\
(-4.40) \\
{[-53.095]}\end{array}$ & $\begin{array}{c}-4.002 \\
(-4.17) \\
{[-50.569]}\end{array}$ \\
\hline Female baby & $\begin{array}{l}0.085 \\
(0.09) \\
{[1.067]}\end{array}$ & $\begin{array}{l}0.072 \\
(0.08) \\
{[0.909]}\end{array}$ & $\begin{array}{l}0.087 \\
(0.09) \\
{[1.105]}\end{array}$ & $\begin{array}{l}0.084 \\
(0.09) \\
{[1.065]}\end{array}$ & $\begin{array}{l}0.067 \\
(0.07) \\
{[0.841]}\end{array}$ \\
\hline Low birth weight & $\begin{array}{c}2.286 \\
(0.94) \\
{[28.853]}\end{array}$ & $\begin{array}{c}2.201 \\
(0.97) \\
{[27.800]}\end{array}$ & $\begin{array}{c}1.769 \\
(0.78) \\
{[22.345]} \\
\end{array}$ & $\begin{array}{c}1.908 \\
(0.79) \\
{[24.105]}\end{array}$ & $\begin{array}{c}1.657 \\
(0.69) \\
{[20.943]}\end{array}$ \\
\hline Very low birth weight & $\begin{array}{l}-0.314 \\
(-0.07) \\
{[-3.969]}\end{array}$ & $\begin{array}{l}-0.425 \\
(-0.10) \\
{[-5.370]}\end{array}$ & $\begin{array}{c}-1.249 \\
(-0.30) \\
{[-15.778]}\end{array}$ & $\begin{array}{l}0.017 \\
(0.00) \\
{[0.212]}\end{array}$ & $\begin{array}{l}-0.127 \\
(-0.03) \\
{[-1.606]}\end{array}$ \\
\hline
\end{tabular}




\begin{tabular}{|l|c|c|c|c|c|}
\hline State unemployment & -0.009 & -0.008 & -0.009 & -0.010 & -0.010 \\
& $(-1.02)$ & $(-1.03)$ & $(-1.20)$ & $(-1.08)$ & $(-1.10)$ \\
& {$[-0.113]$} & {$[-0.105]$} & {$[-0.113]$} & {$[-0.124]$} & {$[-0.121]$} \\
\hline State real income per capita & -0.047 & -0.051 & -0.064 & -0.054 & -0.057 \\
& $(-1.70)$ & $(-1.93)$ & $(-2.52)$ & $(-2.18)$ & $(-2.37)$ \\
& {$[-0.597]$} & {$[-0.642]$} & {$[-0.810]$} & {$[-0.684]$} & {$[-0.721]$} \\
\hline Tax elasticity & -0.179 & -0.170 & -0.156 & -0.168 & -0.157 \\
\hline
\end{tabular}

Note: Z-statistics in parentheses, and intercept not shown. Brackets show marginal effects; the change in the average quarterly SIDS count from a one unit change in the independent variable. Coefficients can be interpreted as the percentage change in the average quarterly SIDS count from a one unit change in the independent variable. All models also include year, quarter, and state dummy variables. N=6,324. 
Table 5: SIDS Counts on Lagged Cigarette Price, Tax and Smoke Free Air Laws

\begin{tabular}{|c|c|c|c|c|c|}
\hline & (1) & (2) & (3) & (4) & (5) \\
\hline Lagged cigarette price & $\begin{array}{l}-0.737 \\
(-4.12) \\
{[-9.304]}\end{array}$ & $\begin{array}{l}-0.719 \\
(-4.48) \\
{[-9.087]}\end{array}$ & $\begin{array}{l}-0.672 \\
(-4.36) \\
{[-8.489]}\end{array}$ & $\begin{array}{l}-0.700 \\
(-4.17) \\
{[-8.854]}\end{array}$ & $\begin{array}{l}-0.668 \\
(-4.25) \\
{[-8.443]}\end{array}$ \\
\hline Lagged SFA: private workplace & & $\begin{array}{l}-0.067 \\
(-1.47) \\
{[-0.844]}\end{array}$ & & & \\
\hline Lagged SFA: restaurant & & & $\begin{array}{l}-0.093 \\
(-4.31) \\
{[-1.178]}\end{array}$ & & \\
\hline Lagged SFA: child care center & & & & $\begin{array}{l}-0.031 \\
(-2.15) \\
{[-0.389]}\end{array}$ & \\
\hline Lagged Smoking ban count & & & & & $\begin{array}{l}-0.114 \\
(-2.76) \\
{[-1.436]}\end{array}$ \\
\hline Price elasticity & -0.820 & -0.801 & -0.748 & -0.780 & -0.743 \\
\hline Lagged cigarette tax & $\begin{array}{c}-1.010 \\
(-4.04) \\
{[-12.760]} \\
\end{array}$ & $\begin{array}{c}-0.968 \\
(-4.33) \\
{[-12.238]} \\
\end{array}$ & $\begin{array}{c}-0.890 \\
(-4.04) \\
{[-11.249]} \\
\end{array}$ & $\begin{array}{c}-0.951 \\
(-4.03) \\
{[-12.025]} \\
\end{array}$ & $\begin{array}{c}-0.896 \\
(-4.05) \\
{[-11.328]} \\
\end{array}$ \\
\hline Lagged SFA: private workplace & & $\begin{array}{l}-0.052 \\
(-1.20) \\
{[-0.663]}\end{array}$ & & & \\
\hline Lagged SFA: restaurant & & & $\begin{array}{l}-0.082 \\
(-3.69) \\
{[-1.039]}\end{array}$ & & \\
\hline Lagged SFA: child care center & & & & $\begin{array}{l}-0.027 \\
(-2.04) \\
{[-0.345]}\end{array}$ & \\
\hline Lagged Smoking ban count & & & & & $\begin{array}{l}-0.100 \\
(-2.53) \\
{[-1.261]}\end{array}$ \\
\hline Tax elasticity & -0.198 & -0.190 & -0.175 & -0.187 & -0.176 \\
\hline
\end{tabular}

Note: Z-statistics in parentheses, and intercept not shown. Brackets show marginal effects; the change in the average quarterly SIDS count from a one unit change in the independent variable. Coefficients can be interpreted as the percentage change in the average quarterly SIDS count from a one unit change in the independent variable. All models also include maternal, infant and state characteristics, and year, quarter, and state dummy variables. $\mathrm{N}=6,324$. 
Table 6: Infant Motor Vehicle and Drowning Fatalities

\begin{tabular}{|c|c|c|c|c|c|c|}
\hline & \multicolumn{3}{|c|}{ Motor Vehicle Fatalities } & \multicolumn{3}{|c|}{ Drowning Fatalities } \\
\hline Annual per capita cigarette sales & $\begin{array}{l}0.003 \\
(2.54) \\
{[0.008]} \\
\end{array}$ & & & $\begin{array}{l}0.001 \\
(0.35) \\
{[0.001]}\end{array}$ & & \\
\hline Real cigarette price & & $\begin{array}{l}-0.225 \\
(-1.06) \\
{[-0.128]}\end{array}$ & & & $\begin{array}{l}0.266 \\
(0.97) \\
{[0.047]} \\
\end{array}$ & \\
\hline Real cigarette tax & & & $\begin{array}{l}-0.237 \\
(-0.84) \\
{[-0.135]}\end{array}$ & & & $\begin{array}{l}0.388 \\
(1.05) \\
{[0.069]}\end{array}$ \\
\hline Smoking ban count & & $\begin{array}{l}0.014 \\
(0.34) \\
{[0.008]} \\
\end{array}$ & $\begin{array}{l}0.017 \\
(0.41) \\
{[0.009]}\end{array}$ & & $\begin{array}{l}-0.050 \\
(-0.76) \\
{[-0.009]}\end{array}$ & $\begin{array}{l}-0.058 \\
(-0.85) \\
{[-0.010]}\end{array}$ \\
\hline Maternal age at first birth & $\begin{array}{l}-0.271 \\
(-3.54) \\
{[-0.599]}\end{array}$ & $\begin{array}{l}-0.186 \\
(-2.08) \\
{[-0.106]}\end{array}$ & $\begin{array}{l}-0.186 \\
(-2.07) \\
{[-0.106]}\end{array}$ & $\begin{array}{l}-0.010 \\
(-0.08) \\
{[-0.007]}\end{array}$ & $\begin{array}{c}0.059 \\
(0.45) \\
{[0.010]}\end{array}$ & $\begin{array}{l}0.058 \\
(0.44) \\
{[0.010]}\end{array}$ \\
\hline High school degree & $\begin{array}{c}0.405 \\
(0.69) \\
{[0.894]}\end{array}$ & $\begin{array}{l}0.451 \\
(0.63) \\
{[0.257]} \\
\end{array}$ & $\begin{array}{l}0.478 \\
(0.70) \\
{[0.273]} \\
\end{array}$ & $\begin{array}{l}-0.007 \\
(-0.01) \\
{[-0.005]}\end{array}$ & $\begin{array}{l}-0.105 \\
(-0.09) \\
{[-0.019]}\end{array}$ & $\begin{array}{l}-0.057 \\
(-0.05) \\
{[-0.010]}\end{array}$ \\
\hline Some college & $\begin{array}{l}-0.392 \\
(-0.40) \\
{[-0.867]}\end{array}$ & $\begin{array}{l}0.311 \\
(0.33) \\
{[0.177]} \\
\end{array}$ & $\begin{array}{c}0.337 \\
(0.36) \\
{[0.192]}\end{array}$ & $\begin{array}{c}1.387 \\
(0.70) \\
{[0.976]}\end{array}$ & $\begin{array}{c}2.051 \\
(1.25) \\
{[0.364]}\end{array}$ & $\begin{array}{l}2.052 \\
(1.24) \\
{[0.364]} \\
\end{array}$ \\
\hline College or more & $\begin{array}{c}0.674 \\
(0.79) \\
{[1.488]} \\
\end{array}$ & $\begin{array}{l}0.344 \\
(0.46) \\
{[0.196]} \\
\end{array}$ & $\begin{array}{l}0.343 \\
(0.46) \\
{[0.196]} \\
\end{array}$ & $\begin{array}{l}1.805 \\
(0.98) \\
{[1.271]} \\
\end{array}$ & $\begin{array}{l}0.801 \\
(0.53) \\
{[0.142]}\end{array}$ & $\begin{array}{l}0.790 \\
(0.52) \\
{[0.140]} \\
\end{array}$ \\
\hline Black & $\begin{array}{l}-2.085 \\
(-3.83) \\
{[-4.605]}\end{array}$ & $\begin{array}{l}-1.776 \\
(-3.53) \\
{[-1.012]}\end{array}$ & $\begin{array}{l}-1.792 \\
(-3.55) \\
{[-1.021]}\end{array}$ & $\begin{array}{l}-0.942 \\
(-0.73) \\
{[-0.663]}\end{array}$ & $\begin{array}{l}-1.441 \\
(-1.44) \\
{[-0.256]}\end{array}$ & $\begin{array}{l}-1.416 \\
(-1.41) \\
{[-0.251]}\end{array}$ \\
\hline American Indian/Alaska Natives & $\begin{array}{l}-3.236 \\
(-1.30) \\
{[-7.149]}\end{array}$ & $\begin{array}{l}-4.143 \\
(-1.80) \\
{[-2.361]}\end{array}$ & $\begin{array}{l}-4.182 \\
(-1.80) \\
{[-2.384]}\end{array}$ & $\begin{array}{l}2.769 \\
(0.38) \\
{[1.950]}\end{array}$ & $\begin{array}{c}4.327 \\
(0.71) \\
{[0.768]}\end{array}$ & $\begin{array}{l}4.632 \\
(0.76) \\
{[0.822]} \\
\end{array}$ \\
\hline Other race & $\begin{array}{l}-0.955 \\
(-0.49) \\
{[-2.109]}\end{array}$ & $\begin{array}{l}-1.783 \\
(-0.91) \\
{[-1.016]}\end{array}$ & $\begin{array}{l}-1.930 \\
(-0.95) \\
{[-1.100]}\end{array}$ & $\begin{array}{l}1.787 \\
(0.83) \\
{[1.258]}\end{array}$ & $\begin{array}{l}-0.235 \\
(-0.08) \\
{[-0.042]}\end{array}$ & $\begin{array}{l}-0.287 \\
(-0.11) \\
{[-0.051]}\end{array}$ \\
\hline Female baby & $\begin{array}{c}-6.753 \\
(-1.18) \\
{[-14.918]} \\
\end{array}$ & $\begin{array}{l}-2.567 \\
(-0.93) \\
{[-1.463]}\end{array}$ & $\begin{array}{l}-2.561 \\
(-0.92) \\
{[-1.460]}\end{array}$ & $\begin{array}{c}15.189 \\
(1.43) \\
{[10.694]} \\
\end{array}$ & $\begin{array}{c}1.653 \\
(0.38) \\
{[0.293]} \\
\end{array}$ & $\begin{array}{l}1.639 \\
(0.38) \\
{[0.291]} \\
\end{array}$ \\
\hline Low birth weight & $\begin{array}{l}-0.443 \\
(-0.06) \\
{[-0.979]}\end{array}$ & $\begin{array}{l}4.747 \\
(1.11) \\
{[2.706]} \\
\end{array}$ & $\begin{array}{l}4.857 \\
(1.15) \\
{[2.769]} \\
\end{array}$ & $\begin{array}{c}29.477 \\
(2.62) \\
{[20.755]}\end{array}$ & $\begin{array}{l}17.528 \\
(2.21) \\
{[3.111]}\end{array}$ & $\begin{array}{l}17.477 \\
(2.22) \\
{[3.102]} \\
\end{array}$ \\
\hline Very low birth weight & $\begin{array}{c}45.237 \\
(2.70) \\
{[99.936]}\end{array}$ & $\begin{array}{l}15.946 \\
(1.96) \\
{[9.088]} \\
\end{array}$ & $\begin{array}{l}16.023 \\
(1.95) \\
{[9.135]}\end{array}$ & $\begin{array}{c}-18.241 \\
(-0.47) \\
{[-12.843]} \\
\end{array}$ & $\begin{array}{l}22.871 \\
(1.26) \\
{[4.059]}\end{array}$ & $\begin{array}{l}23.125 \\
(1.27) \\
{[4.105]}\end{array}$ \\
\hline State unemployment & $\begin{array}{l}-0.043 \\
(-3.02) \\
{[-0.094]}\end{array}$ & $\begin{array}{l}-0.033 \\
(-2.64) \\
{[-0.019]}\end{array}$ & $\begin{array}{l}-0.034 \\
(-2.77) \\
{[-0.019]}\end{array}$ & $\begin{array}{l}-0.039 \\
(-1.42) \\
{[-0.027]}\end{array}$ & $\begin{array}{l}-0.050 \\
(-2.12) \\
{[-0.009]}\end{array}$ & $\begin{array}{l}-0.048 \\
(-2.05) \\
{[-0.009]}\end{array}$ \\
\hline State real income per capita & $\begin{array}{c}0.020 \\
(0.66) \\
{[0.044]}\end{array}$ & $\begin{array}{l}0.035 \\
(1.30) \\
{[0.020]} \\
\end{array}$ & $\begin{array}{l}0.034 \\
(1.30) \\
{[0.019]} \\
\end{array}$ & $\begin{array}{l}-0.070 \\
(-1.18) \\
{[-0.049]}\end{array}$ & $\begin{array}{l}-0.080 \\
(-1.21) \\
{[-0.014]}\end{array}$ & $\begin{array}{l}-0.076 \\
(-1.17) \\
{[-0.014]}\end{array}$ \\
\hline
\end{tabular}

Note: Z-statistics in parentheses, intercept not shown, and marginal effects in brackets. Columns 1 and 4 use annual data and $n=1,632$. Columns $2,3,5$ and 6 uses quarterly data and $n=6,324$. All models also include year and state dummy variables. Quarterly data also include quarterly dummies. 
Table 7: Alternative SIDS Models

\begin{tabular}{|c|c|c|c|c|c|}
\hline & $(1)$ & (2) & (3) & (4) & $(5)$ \\
\hline Real cigarette price & & $\begin{array}{l}-0.651 \\
(-4.05) \\
{[-8.220]}\end{array}$ & $\begin{array}{l}-0.587 \\
(-4.29) \\
{[-7.422]}\end{array}$ & & \\
\hline Real cigarette tax & & & & $\begin{array}{c}-0.907 \\
(-3.98) \\
{[-11.451]}\end{array}$ & $\begin{array}{c}-0.795 \\
(-4.19) \\
{[-10.044]}\end{array}$ \\
\hline Smoking ban count & & & $\begin{array}{l}-0.116 \\
(-2.86) \\
{[-1.463]}\end{array}$ & & $\begin{array}{l}-0.103 \\
(-2.69) \\
{[-1.306]}\end{array}$ \\
\hline Maternal age at first birth & $\begin{array}{l}-0.157 \\
(-2.35) \\
{[-1.990]}\end{array}$ & $\begin{array}{l}-0.127 \\
(-1.78) \\
{[-1.599]}\end{array}$ & $\begin{array}{l}-0.107 \\
(-1.76) \\
{[-1.354]}\end{array}$ & $\begin{array}{l}-0.123 \\
(-1.76) \\
{[-1.551]}\end{array}$ & $\begin{array}{l}-0.107 \\
(-1.72) \\
{[-1.356]}\end{array}$ \\
\hline High school degree & $\begin{array}{l}0.002 \\
(0.00) \\
{[0.023]}\end{array}$ & $\begin{array}{l}-0.475 \\
(-1.16) \\
{[-5.994]}\end{array}$ & $\begin{array}{l}-0.402 \\
(-1.07) \\
{[-5.083]}\end{array}$ & $\begin{array}{l}-0.546 \\
(-1.32) \\
{[-6.886]}\end{array}$ & $\begin{array}{l}-0.456 \\
(-1.20) \\
{[-5.765]}\end{array}$ \\
\hline Some college & $\begin{array}{c}0.860 \\
(0.83) \\
{[10.896]}\end{array}$ & $\begin{array}{l}0.615 \\
(0.62) \\
{[7.757]} \\
\end{array}$ & $\begin{array}{l}0.344 \\
(0.37) \\
{[4.343]} \\
\end{array}$ & $\begin{array}{l}0.578 \\
(0.60) \\
{[7.290]}\end{array}$ & $\begin{array}{l}0.353 \\
(0.38) \\
{[4.463]} \\
\end{array}$ \\
\hline College or more & $\begin{array}{c}0.892 \\
(0.98) \\
{[11.299]}\end{array}$ & $\begin{array}{c}0.799 \\
(0.98) \\
{[10.090]}\end{array}$ & $\begin{array}{c}1.014 \\
(1.41) \\
{[12.808]}\end{array}$ & $\begin{array}{c}0.858 \\
(1.09) \\
{[10.832]} \\
\end{array}$ & $\begin{array}{c}1.047 \\
(1.47) \\
{[13.221]}\end{array}$ \\
\hline Black & $\begin{array}{l}-0.422 \\
(-0.77) \\
{[-5.350]}\end{array}$ & $\begin{array}{l}-0.298 \\
(-0.50) \\
{[-3.762]}\end{array}$ & $\begin{array}{l}-0.349 \\
(-0.57) \\
{[-4.404]}\end{array}$ & $\begin{array}{l}-0.390 \\
(-0.65) \\
{[-4.919]}\end{array}$ & $\begin{array}{l}-0.422 \\
(-0.68) \\
{[-5.333]}\end{array}$ \\
\hline American Indian/Alaska Natives & $\begin{array}{c}6.668 \\
(2.19) \\
{[84.483]} \\
\end{array}$ & $\begin{array}{c}5.986 \\
(2.28) \\
{[75.563]} \\
\end{array}$ & $\begin{array}{c}6.101 \\
(2.08) \\
{[77.098]} \\
\end{array}$ & $\begin{array}{c}5.297 \\
(1.95) \\
{[66.846]} \\
\end{array}$ & $\begin{array}{c}5.516 \\
(1.83) \\
{[69.688]} \\
\end{array}$ \\
\hline Other race & $\begin{array}{c}-6.051 \\
(-4.47) \\
{[-76.672]}\end{array}$ & $\begin{array}{c}-4.362 \\
(-4.49) \\
{[-55.060]}\end{array}$ & $\begin{array}{c}-3.848 \\
(-4.06) \\
{[-48.625]}\end{array}$ & $\begin{array}{c}-4.392 \\
(-4.42) \\
{[-55.426]}\end{array}$ & $\begin{array}{c}-3.997 \\
(-4.11) \\
{[-50.501]}\end{array}$ \\
\hline Female baby & $\begin{array}{l}0.082 \\
(0.09) \\
{[1.034]}\end{array}$ & $\begin{array}{l}0.085 \\
(0.09) \\
{[1.079]} \\
\end{array}$ & $\begin{array}{l}0.062 \\
(0.07) \\
{[0.782]} \\
\end{array}$ & $\begin{array}{l}0.106 \\
(0.11) \\
{[1.337]}\end{array}$ & $\begin{array}{c}0.081 \\
(0.09) \\
{[1.022]}\end{array}$ \\
\hline Low birth weight & $\begin{array}{c}3.681 \\
(1.27) \\
{[46.641]}\end{array}$ & & & & \\
\hline Very low birth weight & $\begin{array}{c}2.336 \\
(0.50) \\
{[29.599]}\end{array}$ & & & & \\
\hline State unemployment & $\begin{array}{l}-0.007 \\
(-0.86) \\
{[-0.091]}\end{array}$ & $\begin{array}{l}-0.007 \\
(-0.82) \\
{[-0.085]}\end{array}$ & $\begin{array}{l}-0.008 \\
(-0.92) \\
{[-0.097]}\end{array}$ & $\begin{array}{l}-0.009 \\
(-1.07) \\
{[-0.118]}\end{array}$ & $\begin{array}{l}-0.010 \\
(-1.14) \\
{[-0.125]}\end{array}$ \\
\hline State real income per capita & $\begin{array}{l}-0.028 \\
(-0.85) \\
{[-0.349]}\end{array}$ & $\begin{array}{l}-0.040 \\
(-1.38) \\
{[-0.507]}\end{array}$ & $\begin{array}{l}-0.053 \\
(-2.22) \\
{[-0.664]}\end{array}$ & $\begin{array}{l}-0.048 \\
(-1.70) \\
{[-0.606]}\end{array}$ & $\begin{array}{l}-0.058 \\
(-2.37) \\
{[-0.728]}\end{array}$ \\
\hline Price/tax elasticity & & -0.748 & -0.675 & -0.181 & -0.158 \\
\hline
\end{tabular}

Note: Z-statistics in parentheses, and intercept not shown. Brackets show marginal effects; the change in the average quarterly SIDS count from a one unit change in the independent variable. Coefficients can be interpreted as the percentage change in the average quarterly SIDS count from a one unit change in the independent variable. All models also year, quarter, and state dummy variables. $\mathrm{N}=6,324$. 